\title{
Flow-switching and water piracy between Rutford Ice Stream and Carlson Inlet, West Antarctica
}

\author{
David G. VAUGHAN, ${ }^{1}$ Hugh F.J. CORR,${ }^{1}$ Andy M. SMITH, ${ }^{1}$ Hamish D. PRITCHARD, ${ }^{1}$ \\ Andrew SHEPHERD ${ }^{2}$ \\ ${ }^{1}$ British Antarctic Survey, Natural Environment Research Council, Madingley Road, Cambridge CB3 OET, UK \\ E-mail:d.vaughan@bas.ac.uk \\ ${ }^{2}$ Department of Geography, University of Edinburgh, Drummond Street, Edinburgh EH9 9XP, UK
}

\begin{abstract}
Rutford Ice Stream and Carlson Inlet are neighbouring glaciers in West Antarctica. Rutford Ice Stream flows at speeds greater than $350 \mathrm{ma}^{-1}$, whereas Carlson Inlet, which has some similar dimensions and supports a similar driving stress, flows 10-50 times slower. We discuss a range of observations concerning Carlson Inlet, and conclude that there is good indirect evidence that it is a relict ice stream, which ceased streaming more than 240 years $\mathrm{BP}$, but sufficiently recently that its surface morphology, basal water content and basal morphology still retain characteristics produced by streaming. An analysis of expected subglacial drainage pathways indicates that Carlson Inlet is not streaming because it is currently starved of subglacial water, which is currently directed beneath Rutford Ice Stream. This current state of water piracy by Rutford Ice Stream is, however, sensitive to minor thickness changes on the ice streams; a $\sim 120 \mathrm{~m}(<4 \%)$ thickening of Rutford Ice Stream would divert almost all the subglacial water in the system towards Carlson Inlet and could reactivate its flow. The result highlights the importance of subglacial drainage in controlling ice-stream evolution and the requirement for ice-sheet models to couple ice flow with subglacial drainage.
\end{abstract}

\section{INTRODUCTION}

The shutdown of Kamb Ice Stream (formerly Ice Stream C) around 130 years ago (Rose, 1979; Retzlaff and Bentley, 1993; Anandakrishnan and Alley, 1997) is significant because it provides evidence for shutdown of an ice stream over a relatively short period, most probably as a result of diversion of basal water into neighbouring Whillans Ice Stream (formerly Ice Stream B; Alley and others, 1994; Anandakrishnan and others, 2001). With the emerging evidence that subglacial hydrology can exhibit highly unsteady behaviour (Gray and others, 2005; Wingham and others, 2006b; Fricker and others, 2007), we are prompted to consider if there are other parts of the Antarctic ice sheet where similar sensitivities exist in ice-stream configuration, that could cause a rapid readjustment of the ice-sheet flow. If such sensitivities prove to be common, it may be difficult to build realistic simulations of ice-sheet evolution without including a coupled model of subglacial hydrology.

This paper focuses on Rutford Ice Stream and Carlson Inlet, West Antarctica (Fig. 1). The discussion is presented in three parts. Firstly, we consider evidence that allows us to test the hypothesis that Carlson Inlet is a relict ice stream. Secondly, we investigate the likely routes of subglacial water transport within the Rutford Ice Stream-Carlson Inlet system, to look for evidence as to why Carlson Inlet is not flowing rapidly at present. Finally, we show that water piracy and possibly flow-switching between Rutford Ice Stream and Carlson Inlet, either in the past or in the future, could be triggered by even modest changes in ice-stream thickness.

\section{RUTFORD ICE STREAM/CARLSON INLET: CONTEXT}

It has been argued that Rutford Ice Stream (Fig. 1, inset) is a 'typical' Antarctic outlet glacier (Doake and others, 2001). It lies in a deep subglacial trough between the Ellsworth Mountains and Fletcher Promontory, and the ice-flow direction is constrained by this topography. Rutford Ice Stream flows at rates of $300-400 \mathrm{~m} \mathrm{a}^{-1}$. This is rather less than the fastest Antarctic ice streams, and is especially low when we consider that Rutford Ice Stream generates a high driving stress calculated by Doake and others (2001) to be $\sim 40 \mathrm{kPa}$, and, using data presented in this paper (Table 1), to be $\sim 55 \mathrm{kPa}$ for the portion within $100 \mathrm{~km}$ of the grounding line. Restraint to flow is generated by both side-wall and basal drag (Frolich and others, 1987), and some of the reasons for the high basal restraint have been demonstrated by seismic acoustic impedance mapping, which has shown a complex subglacial system with considerable variations in the water content in the sediments beneath the ice. It has recently been confirmed, through mapping of microearthquakes, that where the sediments have high water content much of the ice motion is accommodated by deformation in the till, whereas where the sediments have lower water content there is considerable sliding over the bed (Smith, 2006). Furthermore, there appear to be rapid rates of erosion and deposition of till beneath Rutford Ice Stream (Smith and others, 2007).

At its northern end, Rutford Ice Stream shares a $\sim 50 \mathrm{~km}$ long common margin (Fig. 1a) with Carlson Inlet. Although Rutford Ice Stream is rather longer than Carlson Inlet, other dimensions (width and ice thickness; see Table 1) are similar. Furthermore, Carlson Inlet also sits in a deep trough (between Fletcher Promontory and Kealey Ice Rise) and supports a driving stress similar to that of Rutford Ice Stream. However, Carlson Inlet is quite different in one important respect: it flows 10-50 times slower than Rutford Ice Stream. The ice-flow velocity on Carlson Inlet has been measured in several locations (Frolich and others, 1989; Vaughan and others, 2003) and is found to be around 5-35 $\mathrm{m} \mathrm{a}^{-1}$. Such rates are more typical of an ice sheet frozen to its bed than an ice stream. 

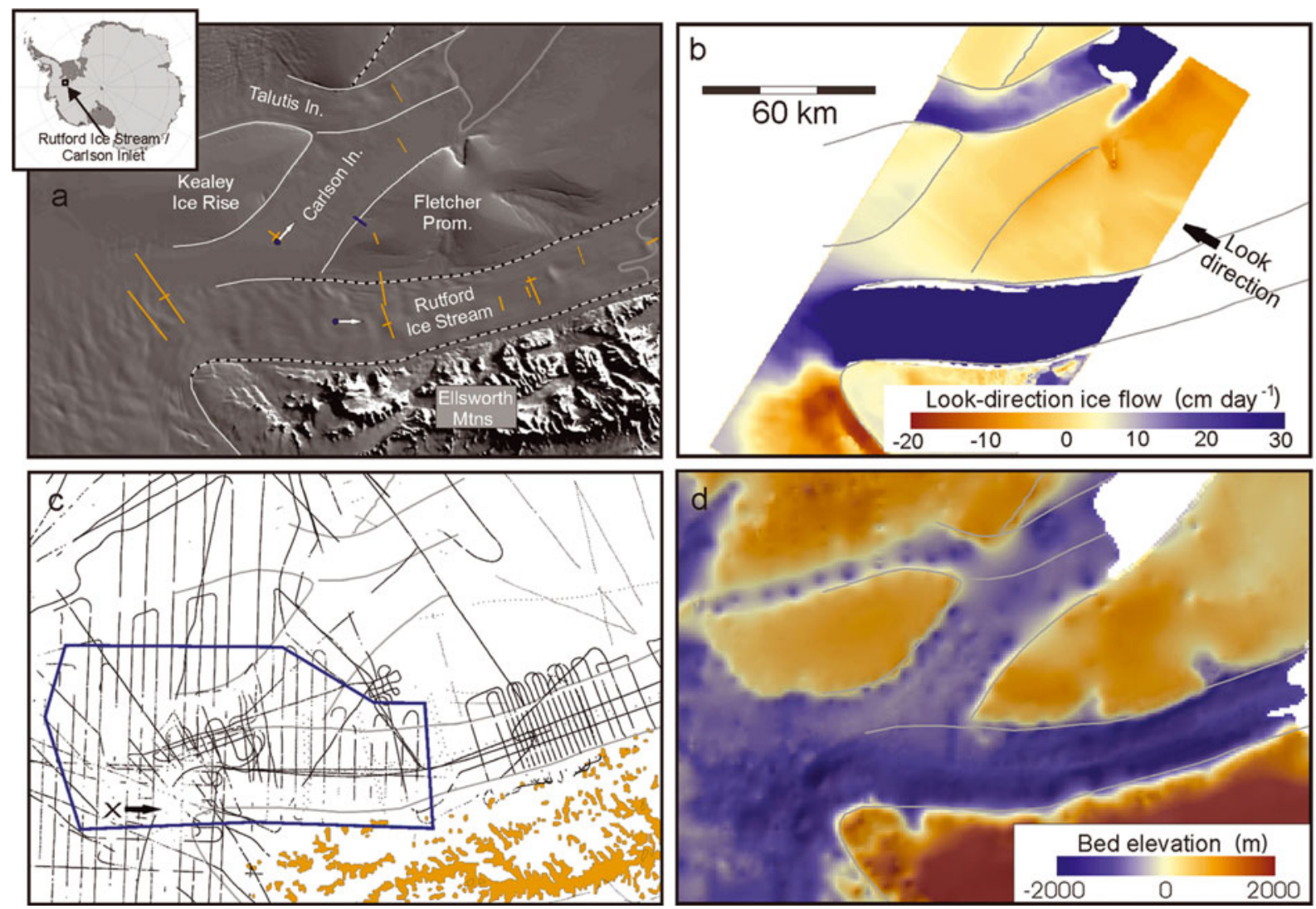

Fig. 1. Frames showing different aspects of the study area. Each frame shows the same portion of West Antarctica (scale in (b) applies to all frames). (a) Locale and glaciological context for Carlson Inlet and Rutford Ice Stream, including place names used in the text. Background image is a mosaic of moderate-resolution imaging spectroradiometer (MODIS) images acquired in 2003 and 2004 (T. Haran and others, http://nsidc.org/data/nsidc-0280.html). Ice-flow directions are shown by white arrows. Blue circles indicate the representative points from which values are taken to populate Table 1. Subglacial acoustic impedance measurements have been made along the seismic lines shown in orange. Crevassed glacier margins are overprinted with black dotted lines. The location of the ground-penetrating radar section shown in Figure 4 is indicated by the blue line. Ice-stream grounding lines are shown in grey. (b) Interferometric synthetic aperture radar (InSAR)derived ice-flow velocities from European Remote-sensing Satellite (ERS) tandem mission images track 92, frames 5499 and 5517 (ERS-1, 12 November 1995; ERS-2, 13 November 1995). Note that most of the ice flow on most of Rutford Ice Stream is $>80 \mathrm{~cm} \mathrm{~d}^{-1}$. This technique measures ice movement in the satellite look direction only; this direction is approximately parallel to the $x$ axis. (c) Surface and bed elevation measurements (black dots) available for construction of digital elevation model (DEM). Rock outcrops are indicated by orange polygons. The irregular blue box shows the extent of the surface DEM used in calculating the hydrological pathways shown in Figures 5 and 6. The $\mathrm{X}$ and arrow indicates the viewpoint of the perspective view shown in Figure 2. (d) The bed elevation DEM.

This disparity in ice velocity is clearly shown in the measured velocity data (Table 1), but can also be seen in the interferometric synthetic aperture radar (InSAR) analysis presented in Figure $1 \mathrm{~b}$. This also indicates that across their common margin there is a strong velocity gradient, even though there are few visible crevasses in high-resolution satellite images (e.g. T. Haran and others, http://nsidc.org/ data/nsidc-0280.html). Upstream, Rutford Ice Stream acquires ice from an extended glaciological basin that curves round to the west of the Ellsworth Mountains, while Carlson Inlet appears to have a much smaller catchment basin.

\section{SURFACE AND BED DIGITAL ELEVATION MODELS}

Several strands of the following discussion rest on an analysis of the surface and subglacial topography on and around Rutford Ice Stream and Carlson Inlet. We have constructed new digital elevation models (DEMs) of surface and bed for these areas, and some brief description of those DEMs is given below.
Ground-based and airborne ice-thickness measurements collected prior to 2000 were compiled for the BEDMAP project (Lythe and others, 2001), and included measurements from researchers over the past 25 years (mostly summarized by Doake and others, 2001). These data were acquired using a variety of techniques. For the present exercise, we selected only data where the uncertainty in ice-thickness measurement was considered less than $\pm 40 \mathrm{~m}$ and the uncertainty in the navigation was likely to be $<1 \mathrm{~km}$. The British Antarctic Survey has also acquired new icethickness data during airborne surveys conducted in this area during the austral summers 1997/98 and 2001/02 (Fig. 1c). These data contain uncertainties in ice thickness of around $\pm 20 \mathrm{~m}$ (Vaughan and others, 2006) and only a few metres of navigational uncertainty. In addition, ice surface elevation was measured during these flights with an accuracy of $\pm 2 \mathrm{~m}$.

Using these data and a simple gridding routine (Topogrid, Arclnfo version 9.0), we have produced DEMs of surface and bed elevation at a grid spacing of $1 \mathrm{~km}$, and these were subsequently smoothed using a $5 \mathrm{~km} \times 5 \mathrm{~km}$ 
moving-average filter. In many areas, the data coverage does not warrant such high-resolution gridding, but in the key region around the junction of Rutford Ice Stream and Carlson Inlet it is justified. The bed DEM (Fig. 1d) clearly shows the broad-scale pattern of troughs in which the glaciers sit, but also reveals detail in the bed topography not previously noted, discussed below.

\section{IS CARLSON INLET A RELICT ICE STREAM?}

Several previous authors (Frolich and others, 1989; Smith, 2000; Doake and others, 2001) have already suggested that Carlson Inlet might have once flowed faster than it does at present and could represent a 'relict ice stream'. However, thus far, no comprehensive discussion of the evidence has been presented. In this section, we discuss evidence relevant to this hypothesis.

\subsection{Surface morphology}

Visible spectrum satellite images for this region have been available since the early 1970s, and their interpretation has already been widely discussed (e.g. Doake and others, 2001). The imagery shows that there are clear margins separating Carlson Inlet from both Fletcher Promontory and Kealey Ice Rise. In several ways, these margins resemble those on active ice streams, and between ice shelves and ice rises. They are linear, with few notable kinks or bends, and they express an abrupt change in slope between the relatively flat surface of Carlson Inlet and the sloping flanks of the neighbouring ice rises. However, while we would usually expect to see crevasses in active shear margins, the margins between Carlson Inlet and Fletcher and Kealey ice rises do not contain crevasses; here our interpretation of the satellite images is confirmed by unpublished reports from several aircraft pilots and fieldworkers.

The surface of Carlson Inlet is much flatter than the surrounding ice rises and resembles an ice stream; however, it does not have the undulations that are characteristic of streaming flow, and which are ubiquitous on Rutford Ice Stream (see Fig. 1a).

Thus Carlson Inlet has some of the morphology typical of an ice stream (the flat surface and linear margins) but does not have the features associated with streaming flow (the surface undulations and crevassed margins).

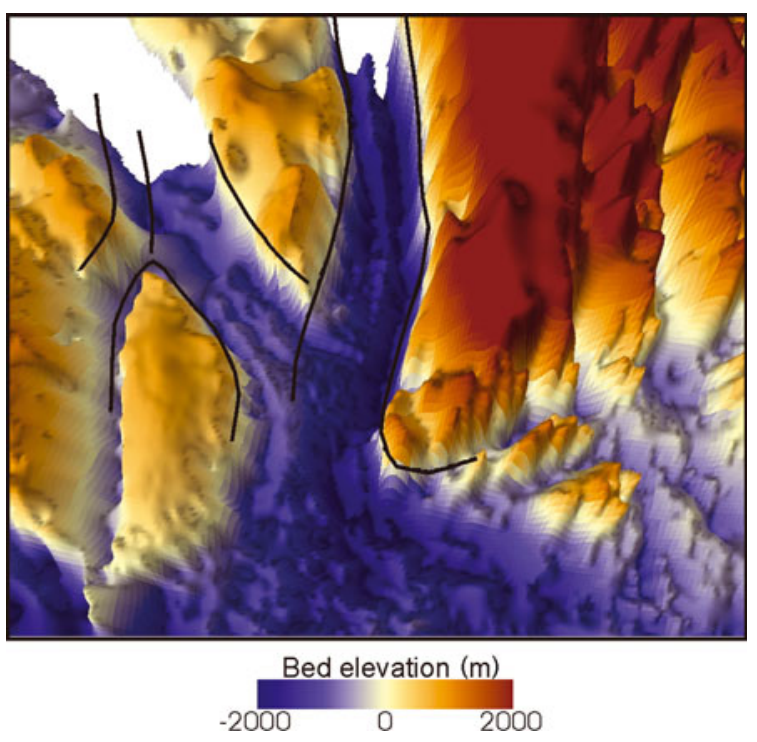

Fig. 2. Perspective view of the subglacial topography of Rutford Ice Stream and Carlson Inlet. The position of the viewpoint and the approximate bounds of the view are shown in Figure 1d. The margins of the ice streams shown in Figure 1a-d are also drawn in the datum $(z=0)$ plane. The bed elevation is represented using the same colour scale as Figure 1d, but is also shaded to accentuate topography. Note the longitudinal feature ( $100 \mathrm{~m}$ higher than the surrounding bed) that runs along the centre of Rutford Ice Stream, and two similar features (truncated by Rutford Ice Stream) that run under Carlson Inlet.

\subsection{Basal morphology}

Our new DEM of the basal topography beneath Carlson Inlet and Rutford Ice Stream shows a level of detail in the subglacial morphology that has not been previously available. In particular, there is an unbroken ridge (Fig. 2) that runs along much of the length of the bed of Rutford Ice Stream following the current ice-flow direction. This ridge is around $5-10 \mathrm{~km}$ wide and up to $500 \mathrm{~m}$ high. Although we cannot rule out a structural/tectonic origin for this longitudinal feature, given the high rates of erosion and deposition that have been observed beneath Rutford Ice Stream (Smith and others, 2007) it is more likely that these ridges are an erosional/depositional feature associated with ice-stream flow. Two similar, but lower (up to $150 \mathrm{~m}$ high), longitudinal ridges run parallel to the ice flow beneath

Table 1. Topographical comparison of upstream portions of Rutford Ice Stream and Carlson Inlet. Point values are taken for representative points indicated in Figure 1a

\begin{tabular}{|c|c|c|c|}
\hline & Rutford Ice Stream & Carlson Inlet & Source \\
\hline $\begin{array}{l}\text { Width } \\
\text { Margins }\end{array}$ & $\begin{array}{l}\qquad 28 \mathrm{~km} \\
\text { Linear margins generally with crevassing }\end{array}$ & $\begin{array}{l}\qquad 30 \mathrm{~km} \\
\text { Linear margins with no crevassing }\end{array}$ & $\begin{array}{l}\text { Satellite imagery (T. Haran and others, } \\
\text { http://nsidc.org/data/nsidc-0280.html) }\end{array}$ \\
\hline Surface slope & $0.3 \%$ & $0.4 \%$ & \\
\hline $\begin{array}{l}\text { Basal topography } \\
\text { Driving stress }\end{array}$ & $\begin{array}{c}\text { Trough, } 1800 \mathrm{~m} \text { below Fletcher } \\
\text { Promontory and foothills of Ellsworth Mtns } \\
54 \mathrm{kPa}\end{array}$ & $\begin{array}{c}\text { Trough, } 1200 \mathrm{~m} \text { below Fletcher } \\
\text { Promontory and Kealey Ice Rise } \\
66 \mathrm{kPa}\end{array}$ & $\begin{array}{l}\text { DEMs derived } \\
\text { for this study }\end{array}$ \\
\hline $\begin{array}{l}\text { Surface elevation } \\
\text { Ice thickness } \\
\text { Velocity }\end{array}$ & $\begin{array}{c}577 \mathrm{~m} \\
2123 \mathrm{~m} \\
315 \pm 3.0 \mathrm{~m} \mathrm{a}^{-1}\end{array}$ & $\begin{array}{c}642 \mathrm{~m} \\
1850 \mathrm{~m} \\
7.2 \pm 2.8 \mathrm{~m} \mathrm{a}^{-1}\end{array}$ & Frolich and others (1989) \\
\hline
\end{tabular}




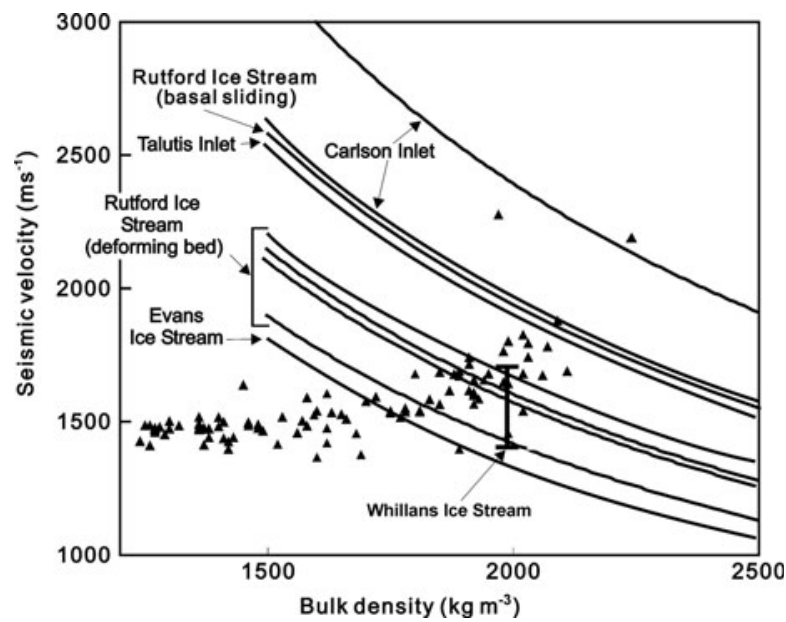

Fig. 3. Published values of density and seismic velocity compared with measured subglacial acoustic impedance for various Antarctic ice streams (modified from Smith, 1997a). Mean acoustic impedance (seismic velocity $\times$ bulk density) for seismic reflection lines on Carlson Inlet, Talutis Inlet, Rutford Ice Stream and Evans Ice Stream (a rapidly flowing ice stream in West Antarctica) are indicated by the hyperbolae. Triangles are from saturated freshwater and marine sediments. The vertical bar is the velocity and density for the bed of Whillans Ice Stream (a rapidly flowing ice stream in West Antarctica) (Blankenship and others, 1987). Note that seismic measurements of acoustic impedance from permafrost and frozenon conditions have suggested seismic velocities in the range 4000$5000 \mathrm{~m} \mathrm{~s}^{-1}$, too high to be shown on this diagram.

Carlson Inlet. These features are clear from the junction between Carlson Inlet and Rutford Ice Stream to its junction with Talutis Inlet. Due to the paucity of ice-thickness data (see Fig. 1b) it is not possible to determine if the features continue beyond this point.

Although it would be easy to overstate the significance of these features, the similarity of the ridges beneath Carlson Inlet and Rutford Ice Stream suggests a common, presumably erosional/depositional, origin. The ridges we now see beneath Carlson Inlet may have been formed by fast flow and then truncated as the flow on Rutford Ice Stream became dominant, and are thus at least consistent with the hypothesis that Carlson Inlet is a relict ice stream.

\subsection{Basal conditions}

Seismic reflection measurements of subglacial acoustic impedance (a material property of the substrate immediately beneath the ice) have provided a direct assessment of basal conditions along longitudinal and transverse profiles on both Rutford Ice Stream (Smith, 1997a, b; Vaughan and others, 2003) and Carlson Inlet (Smith, 2000; Vaughan and others, 2003). These surveys have shown that Rutford Ice Stream is underlain everywhere by wet sediments. In places, these sediments have sufficiently high water content to be dilated and deforming, while elsewhere the sediments are wet but are still lodged (not deforming) (Smith, 1997a, b; Vaughan and others, 2003; King and others, 2004).

Several profiles of acoustic impedance collected on Carlson Inlet (Fig. 3) show rather different basal conditions (Smith, 2000). The subglacial material here has acoustic impedances that are substantially lower than would arise from a frozen bed, where the bed is essentially permafrost (e.g. Smith and others, 2002), but are also considerably higher than seen for deforming sediments under any of the active ice streams studied thus far. Indeed the values of acoustic impedance are higher than even the areas of Rutford Ice Stream that are underlain by wet non-deforming sediments. We thus support the earlier conclusion by Smith (2000) that the material beneath Carlson Inlet is sedimentary and contains water but has a measurably lower water content than is generated by streaming flow, even where subglacial deformation is not present.

This assessment needs to be considered alongside a thermal calculation which indicated that under steady-state conditions Carlson Inlet should be frozen to its bed (Frolich and others, 1989). The implication from the acoustic impedance mapping, that the sediments beneath Carlson Inlet are wet, means that the calculation is incorrect in some aspect. It is possible that the boundary conditions applied in the calculation were incorrect, that Carlson Inlet overlies crust with unusually high geothermal heat flux or that basal temperature is maintained by a subglacial water supply (see section 5). However, a simpler interpretation is that the steady-state assumption is inappropriate and the water in the sediments beneath Carlson Inlet is a relict of a period when it flowed faster and generated substantially more frictional heat than it does today. This would mean that since streaming ceased, the sediments have become partially dewatered, either by drainage or by freeze-on near the bed (cf. Christofferson and Tulaczyk, 2003).

\subsection{Mass balance}

Satellite altimeter data have been used to detect changes in the surface elevation of the Antarctic ice sheet in the periods 1992-2003 (Wingham and others, 2006a) and 1992-2002 (Zwally and others, 2005). In places, these data show clear signals related to ice dynamics, such as the inflation of the Kamb Ice Stream drainage basin that has been ascribed to an imbalance resulting from its shutdown 130 years ago (Anandakrishnan and Alley, 1997; Joughin and Tulaczyk, 2002).

The analyses of satellite altimeter data reported by Wingham and others (2006a) indicate that, while most of the Rutford glaciological basin is thickening at rates of $\sim 5-10 \mathrm{~cm} \mathrm{a}^{-1}$, the basins feeding Carlson Inlet and Talutis Inlet are thickening at rates of $>20 \mathrm{~cm} \mathrm{a}^{-1}$ and $10-15 \mathrm{~cm} \mathrm{a}^{-1}$ respectively (Zwally and others, 2005). The latter rates represent a considerable $(\sim 20 \%)$ fraction of the mean accumulation rate in this area $\left(\sim 400 \mathrm{~kg} \mathrm{a}^{-1} \mathrm{~m}^{-2}\right.$; Arthern and others, 2006). We performed a more detailed assessment of elevation changes at European Remote-sensing Satellite (ERS) orbit crossover locations in each glacier drainage basin. Between 1992 and 2003, the $28500 \mathrm{~km}^{2}$ Rutford Ice Stream drainage basin thickened at an average rate of $7.7 \pm 1.4 \mathrm{~cm} \mathrm{a}^{-1}$, whereas the $9300 \mathrm{~km}^{2}$ Carlson Inlet basin thickened at an average rate of $11.4 \pm 1.3 \mathrm{~cm} \mathrm{a}^{-1}$. The neighbouring $4800 \mathrm{~km}^{2}$ basin of Talutis Inlet also appears to be thickening $\left(14.6 \pm 3.2 \mathrm{~cm} \mathrm{a}^{-1}\right)$.

Although we cannot rule out that the overall imbalance in this area is due to high accumulation rates over the last decade, there are specific differences in the rates of thickening between the individual basins. And while the signal is nowhere near as clear as that seen between Whillans and Kamb Ice Streams, it may be that the difference between the thickening rates for Carlson Inlet and Rutford Ice Stream is due to a long-term imbalance resulting from shutdown, or deceleration of Carlson Inlet relative to Rutford 
Ice Stream. Mass balance across the Rutford Ice Stream and Carlson Inlet basins could be achieved by a flow rate in Carlson Inlet of $\sim 60 \mathrm{ma}^{-1}$.

\subsection{Internal layering}

The existence of a layer of buried crevasses seen on Kamb Ice Stream using ice-penetrating radar (Retzlaff and Bentley, 1993) has allowed a date to be estimated for the shutdown of this ice stream. We have collected ice-penetrating radar sections at several locations on Carlson Inlet (see Fig. 1a); none has shown similar evidence. Both on the trunk of Carlson Inlet and in its margin with Fletcher Promontory, continuous layering is visible to the maximum depth of the radar penetration (Fig. 4). In the margin, this depth is $84.3 \mathrm{~m}$ (ice equivalent depth calculated using the velocity-density relation given by Robin (1975)). Given a mean accumulation rate of $320 \mathrm{~kg} \mathrm{~m}^{-2} \mathrm{a}^{-1}$ (Vaughan and others, 1999), these layers are around 240 years old.

Given that today the main trunk of Rutford Ice Stream shows only a very few crevasses outside its margins, it would not be sensible to argue that the absence of disturbed layers on the trunk of Carlson Inlet is evidence that it has not streamed. However, the fact that Rutford Ice Stream does generate crevasses along most of the length of its shear margins does seem to imply that the lack of buried crevasses in the margins of Carlson Inlet is evidence that Carlson Inlet has not supported ice-flow rates similar to those currently seen on Rutford Ice Stream. The fact that these layers are unbroken to this depth suggests that streaming flow could not have occurred for at least the last 240 years and must have ceased prior to that date (the same point, but with slightly different values, was made elsewhere: Doake and others, 2001).

It is possible that the use of a radar system with the capability to sound deeper into the ice might, in future, reveal buried crevasses deeper in the ice and so allow dating of a shutdown of Carlson Inlet.

\subsection{Current changes}

Frolich and Doake (1998) reported some minor changes in the position of the shear margin, or change in the balance of velocities between Rutford Ice Stream and Carlson Inlet between ground surveys over the periods 1984-86 and 1994-96 and InSAR velocities from 1994 and 1996. They suggested fluctuations in velocity of up to $10 \mathrm{ma}^{-1}$ and that some change might be ongoing in this area. However, more recent work indicates substantial $(\sim 20 \%)$ fortnightly (tidal) variations in the flow rate of Rutford Ice Stream (Gudmundsson, 2006). This suggests that such minor variations should be treated with extreme caution, and could have arisen from aliasing of the measurement periods and fortnightly velocity variations.

We have conducted a direct comparison of a Landsat multispectral scanner (MSS) image (1560-11492, path 225, row 117) acquired on 3 February 1974, with moderateresolution imaging spectroradiometer (MODIS) imagery acquired between 20 November 2003 and 29 February 2004 (T. Haran and others, http://nsidc.org/data/nsidc0280.html), an interval of $\sim 30$ years. This comparison could have been expected to show up changes of the order $1 \mathrm{~km}$, i.e. migration rates of $30 \mathrm{~m} \mathrm{a}^{-1}$ over that period, but actually shows no detectable changes in the positions of the margin between Rutford and Carlson. There is no evidence for ongoing velocity change on either Rutford Ice Stream or Carlson Inlet.
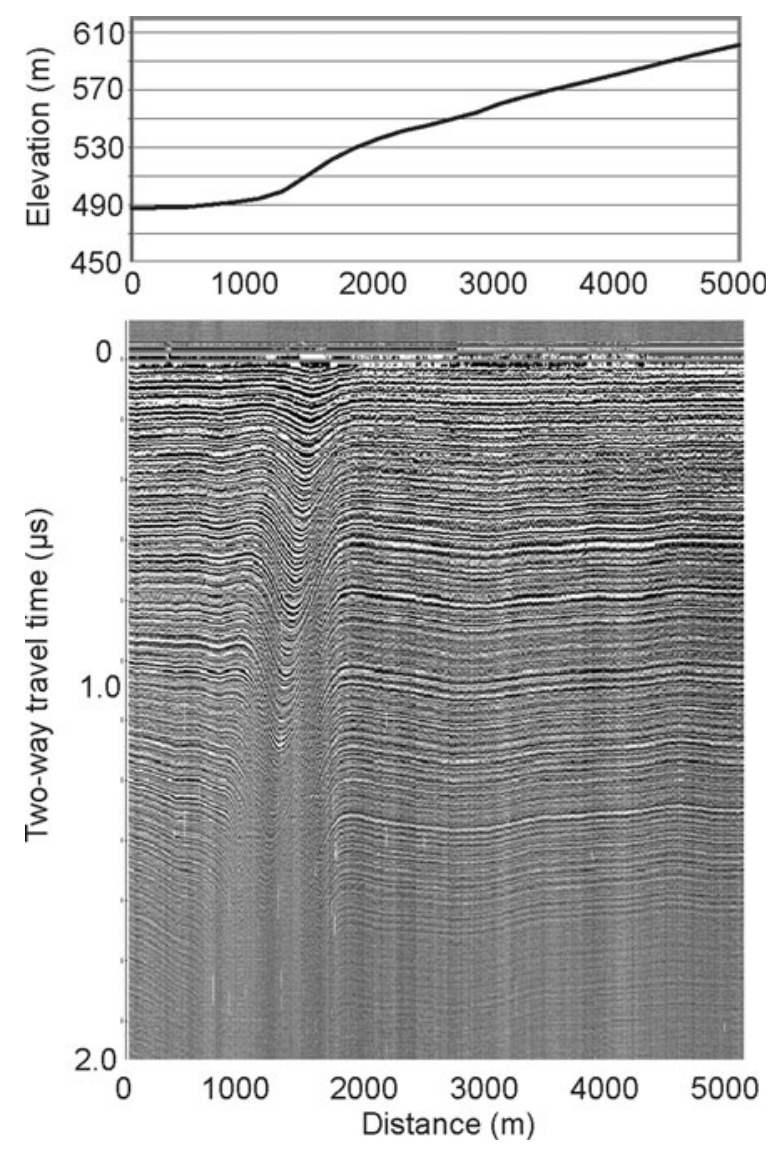

Fig. 4. Topography and radar section measured through the margin of Carlson Inlet onto Fletcher Promontory; location of the line is shown in Figure 1a. Radar data collected using a PulseEKKO 100 operating at $50 \mathrm{MHz}$, an along-track interval of $\sim 5 \mathrm{~m}$. The original data show that layers to at least $1.6 \mu \mathrm{s}$ are continuous across the margin.

\subsection{Summary of evidence}

Taken together, several of the lines of evidence discussed above suggest to us that Carlson Inlet may well be a relict ice stream that shut down sufficiently recently that it retains some of the characteristics of streaming. Linear margins that might be remnants of shear margins are still visible; the bed is composed of partially de-watered basal sediments despite the fact that the steady-state calculation suggests that it should be frozen to its bed; there are strong linear basal topographic features that might be relict erosion/depositional features. The shutdown has perhaps left an overall positive mass balance in the area, which may be being expressed in recent thickening rates in the basins. Indisputable evidence such as buried crevasses may still be lacking, but we find no evidence that contradicts the hypothesis. The lack of buried crevasses in one margin of Carlson Inlet does suggest that any shutdown must have occurred prior to 240 years BP.

\section{WHY IS CARLSON INLET NOT STREAMING TODAY?}

If Carlson Inlet is a relict ice stream, the obvious question is why it does not support fast flow today. The water-piracy model developed to explain the shutdown of Kamb Ice Stream is a candidate here. However, despite promising work (e.g. Kulessa and others, 2003), there is no practical 


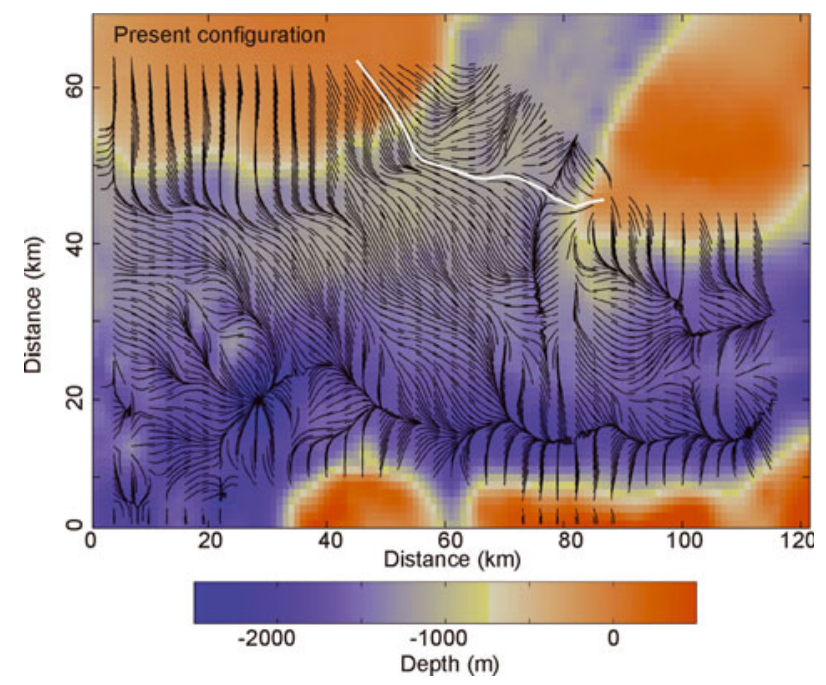

Fig. 5. Gradients in subglacial hydrological potential for the Rutford Ice Stream-Carlson Inlet system calculated on the basis of surface and bed DEMs (Fig. 1d). The gradients are represented by short line segments drawn from grid nodes in the direction down the potential gradient. The subglacial bed DEM is shown for context. The subglacial watershed between Carlson Inlet and Rutford Ice Stream is shown by a white line.

method for tracking subglacial water transport beneath thick glaciers. For this reason we followed the approach taken by authors who have used the concept of hydrological potential to determine the likely paths of subglacial water transport given a particular glacier configuration (e.g. Sharp and others, 1993; Alley and others, 1994; Flowers and Clarke, 1999). Here a calculation based on hydrological potential is informative to indicate the likely routes for water transport, which could be an important control on ice flow.

In this case, we calculate hydrological potential, $\phi$, using a derivation appropriate where water can only exist at the bed at a pressure equal to the overburden pressure of the ice (Sharp and others, 1993).

$$
\phi=\rho_{\mathrm{i}} g h_{\mathrm{i}}+\left(\rho_{\mathrm{w}}-\rho_{\mathrm{i}}\right) g Z_{\mathrm{b}},
$$

where $\rho_{\mathrm{i}}$ and $\rho_{\mathrm{w}}$ are the density of ice and water, $g$ is the acceleration due to gravity, $h_{\mathrm{i}}$ is the surface elevation and $z_{\mathrm{b}}$ is the elevation of the ice bottom. Figure 5 shows the directions of the gradients in hydrological potential calculated for the present configuration of the Rutford-Carlson system on the basis of the bed and surface DEMs described above. The representation shows that the water pathways naturally appear to aggregate into preferential pathways, most notably on the western side of Rutford Ice Stream where they follow the deepest trough beneath the ice stream. This result is not sensitive to the detail of the surface DEM, and a similar pattern has been generated using a lower-resolution surface DEM derived purely from satellite altimetry data (Bamber and Gomez-Dans, 2005).

The subglacial watershed between Rutford Ice Stream and Carlson Inlet is also shown in Figure 5 It reveals that under the present conditions the majority of any water produced under both ice-drainage basins will be routed under Rutford Ice Stream. Essentially, the analysis appears to show that Carlson Inlet is currently starved of subglacial water, and suggests that it does not flow fast because of the water piracy by Rutford Ice Stream.

\section{HOW SENSITIVE IS THE RUTFORD-CARLSON SYSTEM?}

The analysis in section 5, and the similar one by Alley and others (1994) on Kamb Ice Stream, appear to indicate that particular glaciers are not flowing rapidly because their subglacial water is being captured by a neighbour. To investigate the sensitivity to change that exists in the RutfordCarlson system, we performed a series of perturbation analyses shown in Figure $6 \mathrm{a}-\mathrm{c}$. In each, we recalculated the hydrological potential given a perturbation of the present surface DEM intended to simulate a thickening of the ice in particular areas.

To avoid abrupt steps in the hydrological potential, the perturbations we applied to the surface DEM were smooth ones. We applied simple linear ramps to the surface, rising in the negative $y$ direction of Figure $6 a-c$. Since the margin between Carlson Inlet and Rutford Ice Stream is almost parallel to the $x$ direction in this coordinate frame, this satisfactorily mimicked a thickening of Rutford Ice Stream compared to Carlson Inlet. The small ramp had a slope of $2 \mathrm{~m} \mathrm{~km}^{-1}$, to give a thickening of $140 \mathrm{~m}$ at $y=0 \mathrm{~km}$, and $0 \mathrm{~m}$ at $y=70 \mathrm{~km}$. This was equivalent to a thickening of the centre line of Rutford Ice Stream of around $40 \mathrm{~m}$ compared to the centre line of Carlson Inlet.

Figure 6a shows the change in the hydrological pathways and the position of the subglacial watershed between Rutford Ice Stream and Carlson Inlet with respect to the unperturbed case. The first ramp $\left(2 \mathrm{~m} \mathrm{~km}^{-1}\right)$ would have only a slight impact on the position of the subglacial watershed, shifting it only into other areas of slow ice flow where it is likely that little water is currently being generated. It could thus be argued that such a change is unlikely to affect the system substantially.

A thickening of $4 \mathrm{~m} \mathrm{~km}^{-1}$ ( $80 \mathrm{~m}$ thickening of Rutford Ice Stream; Fig. 6b) would result in a rather larger shift in the subglacial watershed, such that Carlson Inlet would capture most subglacial water generated on the interior of its glaciological basin.

A thickening of $6 \mathrm{~m} \mathrm{~km}^{-1}$ (120 $\mathrm{m}$ thickening of Rutford Ice Stream; Fig. 6c) would be sufficient to alter the system dramatically. This configuration would cause routing of a substantial amount of the water generated in the glaciological basins of Rutford Ice Stream and Carlson Inlet beneath Carlson Inlet. And it is known that considerable volumes of water do exist in these basins (King and others, 2004). Under this scenario, it is possible that Rutford Ice Stream would be effectively shut down in favour of Carlson Inlet.

These calculations can only be taken as indicative. There may be important subglacial topography that we have not yet resolved in our survey and which could influence subglacial water transport, and it is unlikely that such simple patterns of thickness change would occur naturally. However, the calculation is sufficient to indicate that a high degree of sensitivity exists in the subglacial water transport beneath the Rutford Ice Stream-Carlson Inlet system. Given the rates of thickness change seen over the last decade, it is feasible that a relative thinning of Rutford Ice Stream has caused Carlson Inlet to shut down within the last millennium.

\subsection{Future behaviour}

The present pattern of surface elevation change shown by the satellite altimeter records does not suggest that the Rutford Ice Stream-Carlson Inlet system is moving towards 
redirecting water transport towards Carlson Inlet. Indeed, further thickening of Carlson Inlet compared to Rutford Ice Stream will act against that outcome. However, this prediction would require that the flow rate of Rutford Ice Stream remains at its present level, and there is now evidence that the velocity of Rutford Ice Stream is extremely sensitive to changes in its boundary conditions. Measurements of surface velocity on Rutford Ice Stream show fortnightly velocity changes of around $20 \%$, that are due to the small changes in basal restraint arising from a non-linear response to the spring-to-neap cycle of the ocean tides (Gudmundsson, 2006). It is thus not unlikely that a secular velocity change of this magnitude could occur relatively quickly. Elsewhere, velocity changes of around $>20 \%$ have been observed over a couple of decades (Joughin and others, 2003). Each year, flow across the grounding line of Rutford Ice Stream removes a volume of ice equivalent to a layer $\sim 4 \mathrm{~m}$ thick over the entire streaming part of Rutford Ice Stream. Thus, a decrease of $20 \%$ in the flow rate of Rutford Ice Stream, even if distributed evenly, would cause a thickening of $0.8 \mathrm{ma}^{-1}$. This amounts to a thickening of $80 \mathrm{~m}$ within a century, which would be sufficient to begin diverting water towards Carlson Inlet. Similar changes could occur perhaps more slowly by differential changes in accumulation rate between the glaciological basins.

\section{CONCLUSIONS}

Several lines of indirect evidence suggest that Carlson Inlet is a relict ice stream that shut down more than 240 years BP. Flow of subglacial water calculated for the current configuration of the Rutford-Carlson system suggests that flow is directed toward Rutford Ice Stream; it is possible that Carlson Inlet shut down because of the effects of water piracy by Rutford Ice Stream.

There is no evidence that streaming flow is restarting on Carlson Inlet at the moment, or that it is imminent; in fact, inflation of Carlson Inlet compared to Rutford Ice Stream as indicated by the satellite measurements of elevation change could imply that it is unlikely in the near future. However, perturbation calculations of the hydrological potentials do indicate a clear sensitivity in the Rutford Ice Stream-Carlson Inlet system, and that thickening of Rutford of $<100 \mathrm{~m}$ could divert significant volumes of water under Carlson Inlet and thereby reactivate streaming conditions. This is only $3 \%$ of the total ice thickness, and a $20 \%$ reduction in the velocity of Rutford Ice Stream would promote such an event on a timescale of around a century.

Although we have argued that Carlson Inlet is a relict ice stream, and there is potential for water piracy between Rutford Ice Stream and Carlson Inlet, we do not have conclusive evidence that the shutdown of Carlson Inlet caused diversion of ice flow into Rutford Ice Stream. However, this does seem likely, since at present there is probably insufficient snowfall to maintain equilibrium if both ice streams were to flow at the rate at which Rutford Ice Stream flows today. This is rather different to the situation in the Whillans/ Kamb ice-stream system, where the shutdown of the flow of Kamb Ice Stream has led to a substantial imbalance in the area and significant inflation of the Kamb Ice Stream basin.

Several recent studies from various parts of Antarctica have shown that the movement of water beneath ice sheets is unsteady and potentially periodic (Gray and others, 2005; Wingham and others, 2006b). This study highlights the
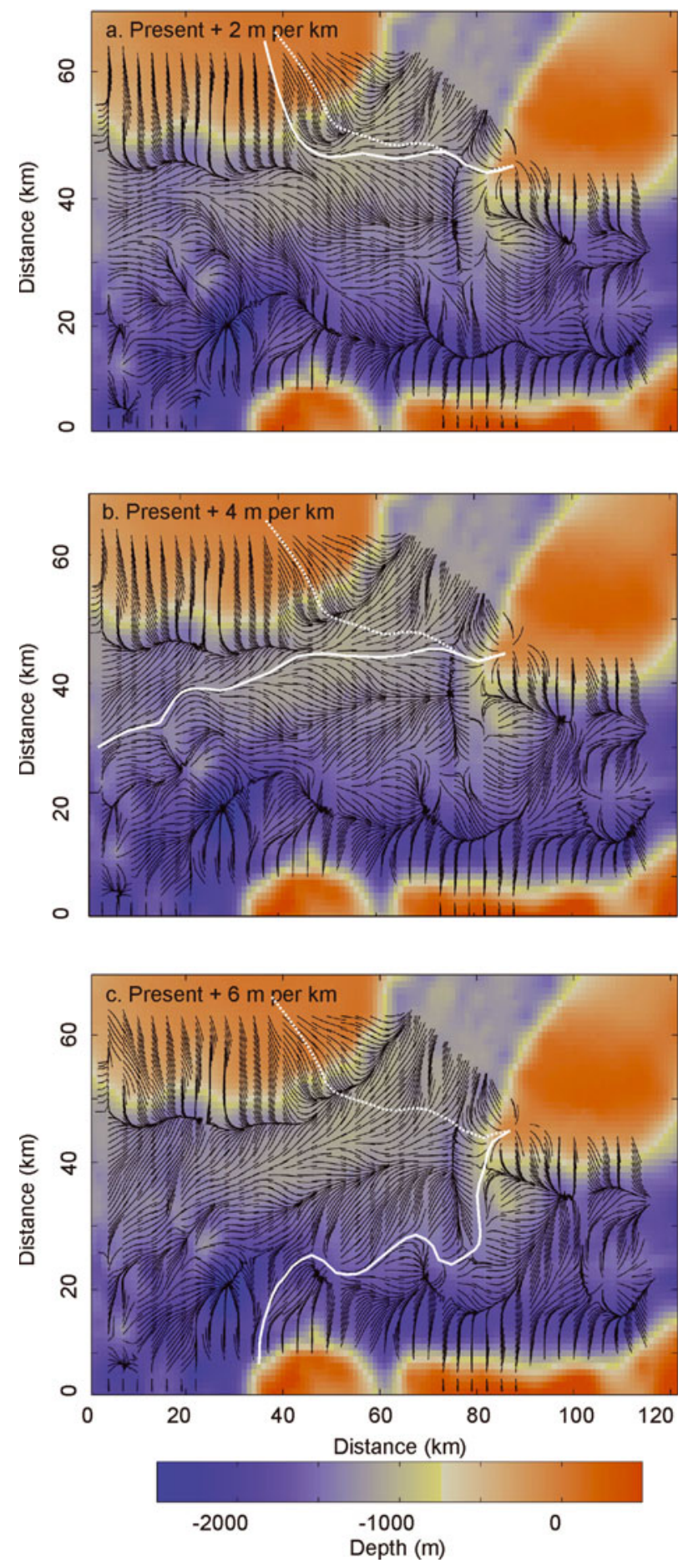

Fig. 6. Gradients in subglacial hydrological potential for the Rutford Ice Stream-Carlson Inlet system calculated on the basis of bed DEM (Fig. 1d) and perturbed surface DEM. The subglacial bed DEM is shown for context. The watershed between water drainage that exits the system beneath Carlson Inlet, and that which exits beneath Rutford Ice Stream is shown by a white line, with the watershed for the unperturbed case (Fig. 5) shown by the white dotted line. (a) (surface $=$ present $-2 \mathrm{~m} \mathrm{~km}^{-1}$ in $y$ direction) representing a thickening of Rutford Ice Stream of $40 \mathrm{~m}$ compared to Carlson Inlet. (b) (surface $=$ present $-4 \mathrm{~m} \mathrm{~km}^{-1}$ in $y$ direction) representing a thickening of Rutford Ice Stream of $80 \mathrm{~m}$ compared to Carlson Inlet. (c) (surface $=$ present $-6 \mathrm{~m} \mathrm{~km}^{-1}$ in $y$ direction) representing a thickening of Rutford Ice Stream of $120 \mathrm{~m}$ compared to Carlson Inlet. 
importance of subglacial water drainage in controlling and maintaining ice-stream flow, and the potential sensitivity of the drainage pathways to ice-thickness changes. Together, they imply that subglacial water transport may be extremely important for a correct understanding of ice-stream and icesheet evolution.

\section{ACKNOWLEDGEMENTS}

We acknowledge support of many British Antarctic Survey field personnel in data-gathering activities, and the intellectual guidance of C.S.M. Doake.

\section{REFERENCES}

Alley, R.B., S. Anandakrishnan, C.R. Bentley and N. Lord. 1994. A water-piracy hypothesis for the stagnation of Ice Stream C, Antarctica. Ann. Glaciol., 20, 187-194.

Anandakrishnan, S. and R.B. Alley. 1997. Stagnation of Ice Stream C, West Antarctica by water piracy. Geophys. Res. Lett., 24(3), 265-268.

Anandakrishnan, S., R.B. Alley, R.W. Jacobel and H. Conway. 2001. The flow regime of Ice Stream $C$ and hypotheses concerning its recent stagnation. In Alley, R.B. and R.A. Bindschadler, eds. The West Antarctic ice sheet: behavior and environment. Washington, DC, American Geophysical Union, 283-294. (Antarctic Research Series 77.)

Arthern, R.J., D.P. Winebrenner and D.G. Vaughan. 2006. Antarctic snow accumulation mapped using polarization of $4.3-\mathrm{cm}$ wavelength microwave emission. J. Geophys. Res., 111(D6), D06107. (10.1029/2004JD005667.)

Bamber, J. and J.L. Gomez-Dans. 2005. The accuracy of digital elevation models of the Antarctic continent. Earth Planet. Sci. Lett., 237(3-4), 516-523.

Blankenship, D.D., C.R. Bentley, S.T. Rooney and R.B. Alley. 1987. Till beneath Ice Stream B. 1. Properties derived from seismic travel times. J. Geophys. Res., 92(B9), 8903-8911.

Christoffersen, P. and S. Tulaczyk. 2003. Thermodynamics of basal freeze-on: predicting basal and subglacial signatures of stopped ice streams and interstream ridges. Ann. Glaciol., 36, 233-243.

Doake, C.S.M. and 7 others. 2001. Rutford Ice Stream, Antarctica. In Alley, R.B. and R.A. Bindschadler, eds. The West Antarctic ice sheet: behavior and environment. Washington, DC, American Geophysical Union, 221-235. (Antarctic Research Series 77.)

Flowers, G.E. and G.K.C. Clarke. 1999. Surface and bed topography of Trapridge Glacier, Yukon Territory, Canada: digital elevation models and derived hydraulic geometry. J. Glaciol., 45(149), 165-174.

Fricker, H.A., T. Scambos, R. Bindschadler and L. Padman. 2007. An active subglacial water system in West Antarctica mapped from space. Science, 315(5818), 1544-1548.

Frolich, R.M. and C.S.M. Doake. 1998. Synthetic aperture radar interferometry over Rutford Ice Stream and Carlson Inlet, Antarctica. J. Glaciol., 44(146), 77-92.

Frolich, R.M., D.R. Mantripp, D.G. Vaughan and C.S.M. Doake. 1987. Force balance of Rutford Ice Stream, Antarctica. IAHS Publ. 170 (Symposium at Vancouver 1987 - The Physical Basis of Ice Sheet Modelling), 323-331.

Frolich, R.M., D.G. Vaughan and C.S.M. Doake. 1989. Flow of Rutford Ice Stream and comparison with Carlson Inlet, Antarctica. Ann. Glaciol., 12, 51-56.

Gray, L., I. Joughin, S. Tulaczyk, V.B. Spikes, R. Bindschadler and K. Jezek. 2005. Evidence for subglacial water transport in the West Antarctic Ice Sheet through three-dimensional satellite radar interferometry. Geophys. Res. Lett., 32(3), L03501. (10.1029/2004GL021387.)
Gudmundsson, G.H. 2006. Fortnightly variations in the flow velocity of Rutford Ice Stream, West Antarctica. Nature, 444(7122), 1063-1064.

Joughin, I. and S. Tulaczyk. 2002. Positive mass balance of the Ross ice streams, West Antarctica. Science, 295(5554), 476-480.

Joughin, I., E. Rignot, C.E. Rosanova, B.K. Lucchitta and J. Bohlander. 2003. Timing of recent accelerations of Pine Island Glacier, Antarctica. Geophys. Res. Lett., 30(13), 1706. (10.1029/ 2003GL017609.)

King, E.C., J.M. Woodward and A.M. Smith. 2004. Seismic evidence for a water-filled canal in deforming till beneath Rutford Ice Stream, West Antarctica. Geophys. Res. Lett., 31(20), L20401. (10.1029/2004GL020379.)

Kulessa, B., B. Hubbard and G.H. Brown. 2003. Cross-coupled flow modeling of coincident streaming and electrochemical potentials and application to subglacial self-potential data. J. Geophys. Res., 108(B8), 2381. (10.1029/2001JB001167.)

Lythe M.B., D.G. Vaughan and BEDMAP Consortium. 2001. BEDMAP: a new ice thickness and subglacial topographic model of Antarctica. J. Geophys. Res., 106(B6), 11,335-11,351.

Retzlaff, R. and C.R. Bentley. 1993. Timing of stagnation of Ice Stream C, West Antarctica, from short-pulse radar studies of buried surface crevasses. J. Glaciol., 39(133), 553-561.

Robin, G.de Q. 1975. Velocity of radio waves in ice by means of a bore-hole interferometric technique. J. Glaciol., 15(73), 151-159.

Rose, K.E. 1979. Characteristics of ice flow in Marie Byrd Land, Antarctica. J. Glaciol., 24(90), 63-75.

Sharp, M.J. and 6 others. 1993. Geometry, bed topography and drainage system structure of the Haut Glacier d'Arolla, Switzerland. Earth Surf. Process. Landf., 18(6), 557-571.

Smith, A.M. 1997a. Basal conditions on Rutford Ice Stream, West Antarctica from seismic observations. J. Geophys. Res., 102(B1), 543-552.

Smith, A.M. 1997b. Variations in basal conditions on Rutford Ice Stream, West Antarctica. J. Glaciol., 43(144), 251-261.

Smith, A.M. 2000. Basal conditions on Rutford Ice Stream and Carlson Inlet: implications for ice stream flow. FRISP Rep. 13, 72-77.

Smith, A.M. 2006. Microearthquakes and subglacial conditions. Geophys. Res. Lett., 33(24), L24501. (10.1029/2006GL028207.)

Smith, A.M., T. Murray, B.M. Davison, A.F. Clough, J. Woodward and H. Jiskoot. 2002. Late surge glacial conditions on Bakaninbreen, Svalbard, and implications for surge termination. J. Geophys. Res., 107(B8), 2152. (10.1029/2001JB000475.)

Smith, A.M. and 6 others. 2007. Rapid erosion, drumlin formation and changing hydrology beneath an Antarctic ice stream. Geology (Boulder), 35(2), 127-130.

Vaughan, D.G., H.F.J. Corr, C.S.M. Doake and E.D. Waddington. 1999. Distortion of isochronous layers in ice revealed by ground-penetrating radar. Nature, 398(6725), 323-326.

Vaughan, D.G., A.M. Smith, P.C. Nath and E. Le Meur. 2003. Acoustic impedance and basal shear stress beneath four Antarctic ice streams. Ann. Glaciol., 36, 225-232.

Vaughan, D.G. and 9 others. 2006. New boundary conditions for the West Antarctic ice sheet: subglacial topography beneath Pine Island Glacier. Geophys. Res. Lett., 33(9), L09501. (10.1029/2005GL025588.)

Wingham, D.J., A. Shepherd, A. Muir and G.J. Marshall. $2006 a$. Mass balance of the Antarctic ice sheet. Philos. Trans. R. Soc London, Ser. A, 364(1844), 1627-1635.

Wingham, D.J., M.J. Siegert, A. Shepherd and A.S. Muir. $2006 \mathrm{~b}$. Rapid discharge connects Antarctic subglacial lakes. Nature, 440(7087), 1033-1036.

Zwally, H.J. and 7 others. 2005. Mass changes of the Greenland and Antarctic ice sheets and shelves and contributions to sealevel rise: 1992-2002. J. Glaciol., 51(175), 509-527. 